\title{
LETTER
}

\section{Timing of renal replacement therapy: is it when or how much?}

\author{
Teja Mahadeshwar', Hansol Kim', Ashish Tikotekar ${ }^{* 2}$ and Amay Parikh²,3 \\ See related research by Leite et al., http://ccforum.com/content/17/2/R62
}

Leite and colleagues addressed the importance of early initiation of renal replacement therapy (RRT) in decreasing mortality and ICU length of stay in patients with Acute Kidney Injury Network stage 3 [1]; however, we have a few concerns regarding the study.

The impact of fluid balance on morbidity and mortality in patients with septic shock, especially with acute kidney injury, cannot be understated [2]. This impact can affect ventilator-free days and the length of ICU stay. The authors did not show their first 6-hour and 24-hour fluid balances.

Whether the reported improvement was due to the timing of initiation of RRT, the dose, or misrepresentation of the study population is an unanswered question. Were improvements seen in morbidity and mortality simply because more volume was removed because of early initiation of RRT or because patients with more severe disease were not represented in the study?

The overall in-hospital mortality in this study was $72 \%$, which is extremely high. In previous prospective studies, the overall mortality rate was just $46 \%$ [3]. Were there other variables in management that were not addressed, such as the time from admission to antibiotic treatment, adequate fluid resuscitation, or initiation vasopressor treatment, which may have led to the high mortality in this population [4]?

\section{Authors' response}

Tacyano Tavares Leite and Alexandre Braga Libório

We appreciate the interest of Dr Mahadeshwar and colleagues in our paper. First, regarding the impact of fluid balance in mortality, we consider this was one limitation of our study as stated in the Discussion section: 'Another limitation is the lack of data on fluid balance, making it especially difficult to explore reasons for reduced mechanical ventilation time in early RRT patients' [1].
Regarding the mortality of our patients, the $46 \%$ mortality rate cited by Mahadeshwar and colleagues refers to the mortality among septic patients having or not having acute kidney injury. In our paper, only patients requiring RRT were included and the majority of patients had sepsis. Chou and colleagues disclosed a similar mortality rate in septic patients needing RRT [5].

\section{Abbreviations}

RRT, renal replacement therapy.

\section{Competing interests}

The authors declare that they have no competing interests.

\section{Author details}

'Internal Medicine Division, Department of Medicine, Robert Wood Johnson Medical School, 1 Robert Wood Johnson Place, PO Box 19, New Brunswick, NJ 08903-0019, USA. ${ }^{2}$ Pulmonary and Critical Care Division, Department of

*Correspondence: ashtik@gmail.com

2Pulmonary and Critical Care Division, Department of Medicine, Robert Wood Johnson Medical School, 1 Robert Wood Johnson Place, PO Box 19, New Brunswick, NJ 08903-0019, USA

Full list of author information is available at the end of the article
Medicine, Robert Wood Johnson Medical School, 1 Robert Wood Johnson Place, PO Box 19, New Brunswick, NJ 08903-0019, USA. ${ }^{3}$ Nephrology Division, Department of Medicine, Robert Wood Johnson Medical School, 1 Robert Wood Johnson Place, PO Box 19, New Brunswick, NJ 08903-0019, USA.

\section{Published: 1 August 2013}

\section{References}

1. Leite TT, Macedo E, Pereira SM, Bandeira SR, Pontes PH, Garcia AS, Militao FR, Sobrinho IM, Assuncao LM, Liborio AB: Timing of renal replacement therapy initiation by AKIN classification system. Crit Care 2013, 17:R62.

2. Bagshaw SM, Brophy PD, Cruz D, Ronco C: Fluid balance as a biomarker: impact of fluid overload on outcome in critically ill patients with acute kidney injury. Crit Care 2008, 12:169.

3. Brun-Buisson C, Doyon F, Carlet J, Dellamonica P, Gouin F, Lepoutre A, Mercier JC, Offenstadt G, Regnier B: Incidence, risk factors, and outcome of severe sepsis and septic shock in adults. A multicenter prospective study in intensive care units. French ICU Group for Severe Sepsis. JAMA 1995, 274:968-974. 
4. Rivers E, Nguyen B, Havstad S, Ressler J, Muzzin A, Knoblich B, Peterson E, Tomlanovich M, Early Goal-Directed Therapy Collaborative G: Early goal-directed therapy in the treatment of severe sepsis and septic shock. N Engl J Med 2001, 345:1368-1377.

5. Chou YH, Huang TM, Wu VC, Wang CY, Shiao CC, Lai CF, Tsai HB, Chao CT, Young GH, Wang WJ, Kao TW, Lin SL, Han YY, Chou A, Lin TH, Yang YW, Chen YM, Tsai PR, Lin YF, Huang JW, Chiang WC, Chou NK, Ko WJ, Wu KD, Tsai TJ; NSARF Study Group: Impact of timing of renal replacement therapy initiation on outcome of septic acute kidney injury. Crit Care 2011, 15:R134. doi:10.1186/cc12797

Cite this article as: Mahadeshwar T, et al:: Timing of renal replacement therapy: is it when or how much? Critical Care 2013, 17:445. 